\title{
Recreational Tourism Development Management in the Region of Caucasus Mineral Waters
}

\author{
Degtyaryova I.N. \\ Department of Information Technologies and Legal \\ Regulation of Management \\ Plekhanov Russian Unoversity of Economics \\ Pyatigorsk, Russia \\ irina_209@mail.ru
}

\author{
Orobinskaya V.N. \\ Department of Food Technology and Commodity Science, \\ School of Caucasus Hospitality \\ Institute of Service, Tourism and Design \\ North-Caucasus Federal University \\ Pyatigorsk, Russia \\ orobinskaya.val@yandex.ru
}

Uzdenova S.B.

Department of Tourism and Hospitality, Institute of Service, Tourism and Design

North-Caucasus Federal University

Pyatigorsk, Russia

uzsony1@yandex.ru

\begin{abstract}
The article discusses the characteristic features of recreational tourism, discloses the problems and prospects of managing its development in the region of Caucasus Mineral Waters. The authors strive to follow the process of existence and further development of the tourist and recreational potential of the region, to meet the needs of the population in tourist services. Considerable attention was paid by the authors to the calculation of the objective needs of the population in spa treatment and rehabilitation, since the region of Caucasus Mineral Waters is one of the main sanatorium-resort complexes of Russia. Reorientation of economic technologies, tourist flow to domestic destinations; work on the creation and operation of competitive recreation areas on the region of Caucasus Mineral Waters is an urgent task in the field of import substitution in recreational tourism.
\end{abstract}

Keywords-recreational tourism; recreational potential, recreational resources; tourist flow; tourist and recreational complex.

\section{INTRODUCTION}

The tourism industry is one of the fastest growing sectors of the Russian economy with the prospect of access and real competition with leading European resorts based on traditions and characteristics of the natural and cultural heritage. And how remarked V.V. Putin: "The tourism industry in the world is developing steadily, and its share in national economies is growing, and it is natural that there is a fierce competition for tourist flows, in order to attract foreign visitors and at the same time make their own citizens prefer to relax in their country ". "We have conceded in this competition for a long time, and inferior significantly," - the president stated. - "First of all, due to the underdeveloped tourism infrastructure and the low quality of service" [1].

The concept of "recreational tourism" implies a type of tourism, the purpose of which is treatment and rest, restoring the physical, mental and adaptive systems of the human body.

Conventionally, recreational tourism is divided into two types:

- the first type is a tourist-health (health-improving), which includes: rest, treatment; restoration (recreation), recovery;

- the second type - educational and tourist, for the existence of which the presence of historical and cultural potential is necessary [2].

Each type of recreational tourism is based on the use of a certain type of recreational resources. The analysis showed that according to the research of domestic scientists, the following types of tourism exist, including recreational (Fig. 1. $[2,3,4,5,6,7,8,9,10])$.

As we know, recreational resources are all that can be used for recreation, tourism and treatment, i.e. phenomena and objects of nature and human activity.

For example, climatic factors are indispensable for tourist and recreational tourism, which, in combination with mineral water sources and healing mud, create favorable conditions for the formation of medical and health services (resort complex) [3]. For educational and tourist tourism, a historical and cultural heritage is necessary.

The recreational potential of the national economy exists and develops not only in the presence of climatic and infrastructural conditions, but also with the necessary financial investments to organize the restoration of health and recreation of the population (table 1). 
sanatorium, engineering and auxiliary facilities. A large number of sanatoriums of various medical profiles, boarding houses, hotels, camp sites, polyclinic networks, as well as buildings for balneotherapy, mud baths, solariums, pump rooms, diagnostic and treatment centers, laboratories are part of the resort.

The resource potential of the Caucasus Mineral Waters is significant and diverse. The features of the relief and climate are healing factors unique to the production of recreational services. A variety of mineral waters, therapeutic muds and other tourist and recreational resources of the region complement each other and make up a valuable socio-cultural potential of the tourism sector, which allows satisfying the needs of tourists not only in recreational, but also in ecological, sports, ethnic, corporate and other types of tourism.

Cognitive tourism is developing due to the presence of historical and cultural heritage in the resorts of the Caucasus Mineral Waters (CMW).

The historical and cultural potential was formed as a result of the presence of favorable natural factors and a convenient geographical location, which have long attracted people from all over Russia and other countries, many of which have left their mark on the history of this region.

Consequently, Caucasus Mineral Waters is a unique tourist and recreational complex, which has all the conditions that can form the necessary sociocultural potential to meet the needs of vacationers, not only in the medical and recreational direction, but also in other types of tourism.

A rich resource base, recreational specialization, and good transport accessibility are the main factors for the further development of recreational tourism on the CMW.

The current state, development and operation of the CMW, is based on the program for the development of priority sectors of the economy of the Russian Federation Tourist and recreational cluster".

The purpose of the "Tourist and Recreational Cluster" is to increase the attractiveness and efficiency of the tourist and recreational complex, taking into account health-improving natural resources and bringing the cluster to world standards and transforming the CMW, as E. Zolotova notes "into a modern, highly effective tourist and recreational and tourist a sports center providing opportunities to meet the needs of Russian and foreign tourists".

Tourist-recreational cluster is a complex of interconnected organizations involved in the development, production, promotion and sale of a tourism product, as well as activities related to tourism and recreational services. [4]

An analysis of the dynamics of development of recreational tourism is carried out on the basis of regional characteristics of the state of the recreation market and taking into account the specifics of the tourism product in a particular resort region.

Toughening of hotel services standards, competition in the hospitality industry, rising costs for the construction and
The health resorts of the Caucasus Mineral Waters are a complex system that includes a variety of medical, 
company KaratHolding, the construction of the tourist and recreation complex "Novopyatigorsk Lake" in Pyatigorsk and others.

Today, the region is simultaneously reconstructing and constructing more than 20 objects of the spa complex, the implementation of which will make it possible to commission about 2,000 new accommodation facilities, as well as create about 1,500 new jobs.

The development program "Culture and Tourism and Recreation Complex" includes the integrated development of the tourism industry in the Stavropol Territory, including the development of the spa complex of the Caucasus Mineral Waters. The implementation of 50 investment projects for the reconstruction and construction of new facilities of the complex is planned.

The basis of the tourist potential of the region is 107 spahotels and 189 other accommodation facilities. All resorts are multi-disciplinary, which allows them to accept people with various diseases. The capacity of rooms, both in sanatoriums and hotels, is constantly expanding. Over the past few years, more than 120 facilities have been commissioned with a capacity of almost 4 thousand places.

The group of Caucasus Mineral Waters resorts includes cities such as Kislovodsk, Essentuki, Zheleznovodsk and Pyatigorsk. These are small cities comparable in size to European resort centers such as Karlovy Vary and BadenBaden. All of them are close to each other and form a single resort area.

The throughput capacity of each resort city of the Caucasus Mineral Waters is different from each other [13, 14]. Data on the number of spa facilities, spa-hotels, hotels, boarding houses are shown in table 2 .

TABLE 2. THE NUMBER OF ACCOMMODATION FACILITIES FOR RECREANTS IN THE CITIES OF CMW growing for several years in a row. So, financing from the federal budget over the past 7 years has grown more than 6 times (from 43 million rubles in 2012 to 270 million in 2018). In total, financing from the state budget of this resort from 2012 to 2018 amounted to 545 million rubles.

Financing from regional budgets, over the same period, increased from 3 million rubles. up to 17.3 million rubles. and as a result amounted to 91.7 million rubles. Of extrabudgetary funds, funding also increased: from 30 million in 2012 to 661 million in 2018 and amounted to about 1.5 billion rubles.

In order to achieve a balanced solution to the problems of preserving the environment, its natural resource potential and integrated socio-economic development, the investment policy is being consistently implemented in the region and a favorable investment climate is being created.

Recently, the interest of domestic and foreign investors in the Caucasus Mineral Waters has been growing, their willingness to invest their money in tourist and recreational development, for example, it is planned to implement an investment project on the reconstruction of the Akademichesky Spa-hotel in Kislovodsk by the Azerbaijani

\begin{tabular}{|l|c|c|c|c|}
\multicolumn{7}{|c}{ City } & $\begin{array}{c}\text { Total number of } \\
\text { accommodation } \\
\text { facilities }\end{array}$ & $\begin{array}{c}\text { Spa- } \\
\text { hotels }\end{array}$ & Hotels & $\begin{array}{c}\text { Boarding } \\
\text { houses }\end{array}$ \\
\hline Pyatigorsk & 107 & 19 & 85 & 3 \\
\hline Kislovodsk & 100 & 38 & 50 & 12 \\
\hline Essentuki & 62 & 29 & 31 & 2 \\
\hline Zheleznovodsk & 27 & 21 & 4 & 2 \\
\hline
\end{tabular}

The Caucasus Mineral Waters region is the largest and most unique resort region of the Russian Federation, which can provide significant health improvement for at least 1 million people in year. This circumstance, which is extremely important for the national interests of Russia in the conditions of a demographic decline and deterioration of the population's health, determines the main direction of development of the Caucasus Mineral Waters region and the need for its state support.

Due to the increasing incidence of the population, in recent times, the objective need for recreational tourism, in particular, for sanatorium-resort treatment and rehabilitation, is especially relevant. 
The general regulatory need (GRN) for spa treatment is determined by the formula:

$$
G R N=N S / 10.000 * N P_{x}
$$

where NS is the specific norm of scientifically based needs for rehabilitation (per 10 thousand people);

\section{$\mathrm{NP}$ - the country's population.}

The calculation of the GRN in the Russian Federation is:

$$
396.6 * 146.8=5.82 \text { million people / places }
$$

Consequently, the general regulatory need for spa treatment in the current period in Russia is 5.82 million. people / places.

\section{RESULTS}

Regular prophylaxis and treatment in sanatoriums significantly reduce temporary disability and increase life expectancy by $3-15$ years.

Treatment and rehabilitation at multidisciplinary resorts is considered one of the most expensive in the world, while it is highly profitable. Recreational health improvement, based on methods developed by specialists of the State Research Institute of Balneology, located in the Pyatigorsk, is considered the most cost-effective, because the post-resort period of time leads to a distinct reduction in labor and material losses.

The average indicator of economic efficiency per year, after undergoing spa treatment, for each vacationer is approximately equal to 25 thousand rubles.

The Stavropol Territory (in the territory of which Caucasus Mineral Waters are located) accounts for almost 19\% of the total sanatorium and resort complex of Russia (according to this indicator the Stavropol Territory is in first place in the Russian rating), and by 2030 they plan to increase this share to $30 \%$ [7].

About $40 \%$ of all vacationers come to CMW from central Russia, $11 \%$ of tourists are residents of the Stavropol Territory, the rest are vacationers from countries such as Azerbaijan, Armenia, Uzbekistan, Belarus, Ukraine. The season at the resort lasts all year round, so for the last few years the occupancy rate of health resorts, hotels and hotels has not dropped below $90 \%$ in the winter months, in the autumn and spring periods it is about $70 \%$, and in summer it can exceed $100 \%$.

In this regard, there is a need to expand the range of resort services and their differentiation in cost, the creation of a network of small hotels, boarding houses, holiday homes [15].

The resort and recreation complex of the Caucasus Mineral Waters occupies a leading position in the market of tourist services, but, nevertheless, is inferior to resorts abroad, such as resorts in Germany and Hungary. I would like to highlight that our resorts lag behind others only in matters relating to the development of the quality characteristics of tourist accommodation, as well as the services provided to them. At the same time, the natural resource potential remains unchanged.

Strengthening the diagnostic and treatment base when stimulating demand during the off-season period with the help of special recreational programs and differentiating the price gap for services makes it possible to increase the degree of stability of the situation, because in relation to the Caucasus Mineral Waters, therapeutic factors, in addition to recreational ones, have an important impact on demand. Demand for health services is least affected by seasonal fluctuations.

However, recreants require from the Caucasian resorts not only medical types of recreation. As a result, the region significantly increases the share of cultural, educational, extreme sports, environmental, gastronomic, event tourism, etc., more than 100 new excursion routes have been created.

Strengthening tourism and recreational activities in the region requires a comprehensive, interconnected approach to the development of certain areas of tourism.

It is necessary not only to constantly increase the effectiveness of recreational tourism, but also to develop new types of services, using both foreign experience and the rich experience of domestic traditions of recreation. Without improving the quality of the entire social, domestic and cultural sphere, without expanding the animation service, creating a modern leisure industry, it is impossible to effectively use the regional resource potential and attract tourists, including those from far abroad.

All this contributes to an increase in the flow of recreants, which, in turn, are a source of income for diversified small enterprises and, ultimately, an increase in the tax potential of the region, an increase in the fiscal sustainability of local municipal bodies, and an increase in the standard of living of the population.

For the development of recreational tourism, an assessment of the recreational potential of the territory, i.e. the totality of natural, cultural, historical and socio-economic prerequisites for organizing recreational and tourism activities. It is the natural resource potential that is the basic basis for the economic development of recreational territories, and this affects both the economic and environmental forms of interaction between society and nature. The economic form, as a rule, is focused on the use, consumption, transformation of nature to ensure the economic interests of society, and the environmental - expresses the environmental interests of society in a high-quality, environmentally friendly, healthy, productive and multi-purpose environment, as a biological the basis for meeting the needs of society for recreational and tourism services.

The development of resorts in the North Caucasus, in particular, Caucasus Mineral Waters, also contributes to the development of related industries in the region: agriculture, food and light industry, transport infrastructure, production of building materials and other market segments. Around the developing resorts, "growth points" are created that attract investment, create new jobs, generate a stream of tax deductions [9]. Tourism here can act as a means and way to solve a set of socio-economic problems. 
[3] Romanova M.M., Kul'gachyov I.P. Innovatsionnye tekhnologii v turizme i gostepriimstve. Moskovskaya akademiya predprinimatel'stva pri Pravitel'stve Moskvy. Vestnik Akademii. 2017, 2, pp. 105-110.

The formation of a market for recreation and tourism is a good prospect for the national economy as a whole and, accordingly, will contribute to the increase of the country's national income. Such a potential contribution of the tourism industry to the country's economy is possible only with the participation of state policy that is able to ensure economic stability and control.

An effective method of development in the field of tourism and recreation is to attract private or small state targeted investments on the basis of projects for the reconstruction or development of existing hotels, resorts, resorts, camps or other facilities. Such projects do not require a lot of time in implementation, do not include high costs, quickly pay off and will be able to meet the growing demand for domestic tourism services.

For the further development of the Caucasus Mineral Waters region as a resort-recreational and health-improving region, it is necessary to ensure effective state regulation, a well-thought-out urban planning policy, the allocation of productive forces, the organization of agricultural production, in the interests of protecting the natural environment and the priority development of resorts.

Taking into account the reorientation of the tourist flow to domestic destinations, the work on the creation and operation of the Caucasus Mineral Waters region of competitive recreation areas is relevant from the point of view of import substitution in tourism.

\section{References}

[1] Rossiyskaya gazeta. "Vladimir Putin: nuzhno razvivat' vnutrenniy turizm». URL: http://www.rg.ru/2015/08/17/putin-site.html

[2] Yanovskiy, V. S. Kurortnye goroda Rossii kak ob"ekt upravleniya v kontse XIX — nachale XX veka. Kislovodsk. 2010, pp. 216
[4] Zolotova E. V. Napravleniya rekreatsionnogo razvitiya regiona KMV, Vestnik SGUTiKD. 2011, 1 (15), pp. 21-25

[5] Taranenko O.N., Ponamareva M.V. Otsenka i perspektivy razvitiya turistsko-rekreatsionnogo klastera regiona SKFO, Voprosy ehkonomiki i upravleniya. 2016, 2 (4), pp. 73-75

[6] Ogarokova I.V. Problemy i perspektivy razvitiya turistkorekreatsionnogo kompleksa kavkazskikh Mineral'nykh Vod, Sovremennaya nauka i innovatsii. 2013, 4, pp.7-14

[7] Shinkarev A. S. Osnovnye printsipy organizatsii sanatornokurortnykh uslug v Rossii i za rubezhom: sravnitel'nyy analiz. Nauchno-metodicheskiy ehlektronnyy zhurnal «Kontsept». 2017, S5. URL: http://e-koncept.ru/2017/470071.htm.

[8] Gosudarstvennaya programma «Razvitie Severo-Kavkazskogo federal'nogo okruga» na period do 2025 goda.

[9] Molchanov G.I., Bondarenko N.G., Degtyareva I.N., Kubalova L.M., Molchanov A.A. Sanatorno-kurortnoe delo: uchebnik. M.: Al'fa-M. 2012, 400.

[10] Razvitie Industrii turizma. URL: http://infocentrkmv.ru/tour-stavkray/razvitie-industrii-turizma

[11] Sushchenko, E.N. Perspektivy razvitiya v regione KavMinVod. URL: https://superinf.ru/view helpstud.php?id=2052

[12] Razrabotka modeli realizatsii strategii razvitiya sanatorno-kurortnogo i turistsko-rekreatsionnogo kompleksa KMV. Pyatigorsk. 2012, pp. 212.

[13] Taran O.L., Adzhienko V.L., Taran I.L., Sergeyeva EU.A. "Sanatoriumresort and tourist sphere for the competitiveness of stavropol territory (part 1)", The European proceedings of social \& behavioural sciences EPSBS CIEDR 2018. Future Academy. 2019, pp. 1055-1059

[14] Alexsandr S. Kuznetsov. Russian Professor's meeting. Russian Journal of Physical Education and Sport. 2019, 14(1), pp. 17-22. DOI: 10.14526/2070-4798-2019-14-1-18-24

[15] Kuznetsov S.A. Model of specialists legal and regulatory training in the Sport. pp. 117-124. DOI: 10.14526/2070-4798-2018-13-3-157-166.

[16] Taran O.L., Adzhienko V.L., Taran I.L., Sergeyeva EU.A. "Sanatoriumresort and tourist sphere for the competitiveness of stavropol territory (part 2)", The European Proceedings of Social \& Behavioural Sciences EpSBS CIEDR 2018. Future Academy. 2019, pp. 1060-1064. sphere of social tourism. The Russian Journal of Physical Education and 